\title{
EFFECTS OF POINT-PIN REWARD METHOD TOWARDS STUDENTS' INTEREST AND ACQUISITION
}

\author{
Nanik Setyaningsih dan Djukri \\ Postgraduate Proggramm Universitas Negeri Yogyakarta \\ email: naniknanings@gmail.com
}

\begin{abstract}
This study was aimed at determining the effect of the point-pin reward method in Biology cross-specialization learning activities towards students' interest and acquisition in the $11^{\text {th }}$-grade social science class in State Senior High School 1 Sentolo. The research was a quasi-experimental study using a pre-test and post test non-equivalent control group design. The number of participants consisted of 41 students divided into 2 classes, the control class and the experimental class. Data for students' interest in learning were collected using interest questionnaires analyzed using a Likert scale. Data for students' acquisition were obtained by analyzing written tests. Research data were analyzed using independent-samples $t$ test. The results of this study indicate that: The point-pin reward method has significant effects on the students' interest and acquisition in the learning activities of biology crossspecialization lessons.
\end{abstract}

Keywords: point-pin reward method, learners' interest, learners' acquisition

\section{INTRODUCTION}

The background of the study begins with the government's efforts to change the national curriculum at the levels of education in Indonesia, including the content standard (CS), basic competency standard (BS), graduating standard (GS), process standard (PS), and assessment standard (AS) (Permendikbud Numbers 22 and 23, 2016). With the change of curriculum, the purpose of national education pursuant to UU No 20 year 2003 can be expectedly achieved.

The curriculum has a number of activities to master and develop the learning materials so that they have a good influence on students' learning. (Slameto, 2010, p. 65). The curriculum of the State Senior High School (SSHS) is developed under the format of the national curriculum in establishing national standards as a minimum quality of learners including attitudes, knowledge, and skills. In the implementation of the 2013 curriculum, SSHS 1 Sentolo has 2 major classes consisting of MIPA (mathematics and natural Sciences) and IPS (social sciences). The cross-specialization subjects that can be selected by IPS students are mathematics, biology, physics, and chemistry.

The problems in the learning activities of cross-specialization biology in the social class is lack of participation, students' response and the students' acquisition in biological learning activities. This situation makes the teachers work extra to improve the quality of learning.

By the implementation of the pointpin reward method in learning activities, students are expected to be actively motivated in participating in the learning process. The point-pin reward point-pin is still rarely applied by teachers, especially at the high school level. With the application of this method, it is expected to increase activities to influence the interest and 
learning outcomes of students. Lee and Fradd stated that teachers need to appreciate students during introducing scientific views to students (Zain, 2017) so that they acquire growing interest, confidence, and success expectations. They will enjoy more academic assignments and learn more when they feel competent (National Research Council, 2003).

Reward is something that is given to someone when making good behavioral changes or doing a good job. Lucrative rewards can attract and retain talent (Delves, 2004, pp. 22-32) Students must also be given time to develop interest in the material (Downing, 1997, pp. 7-39).

Hover stated that external rewards are necessary because they are effective at stimulating actual interest. Rewards can be used to create self-motivation and self-discipline (Hamalik, 2015, p. 163). Reward-giving imbalance will result in academic fatigue and learning saturation in students (Lee, Puig, \& Lee, 2011). If the work is satisfying, then students are interested in exploring new things, thus becoming successful and valued for their contributions (Chahal, 2008, pp. 92-121). Awards are used to support participants' engagement so they are motivated and productive (Armstrong \& Brown, 2006, pp. 2-3). Students who are regularly and systematically rewarded tend to work better (Slameto, 2010, p. 181).

Reward is an educational tool used to educate students to feel happy during learning activities because what they do is rewarded (Purwanto, 2011, p. 182). The function of giving gifts to strengthen individual opinions/beliefs that the actions performed are true or justified (Arikunto, 1990, p. 166).

The special purpose of reward giving is based on the beliefs of what is appreciated and wants to achieve, creating values, supporting the development of work culture, delivering the message, behaviour and correct results, assisting in the process of motivating people and Achieving high involvement (Armstrong \& Brown, 2006, pp. 7-8) and to improve and improve students' achievement (Purwanto, 201stated that point-pin reward is a reward that contains praise and is realized in the form of signs or symbols that are fun and interesting (Hamid, 2006). The reward functions to make students proud and improve their participation in learning activities. Reward conditions include knowing the right students and apprecising them appropriately, do not cause jealousy and envy, do not reward too often, do not give a reward before there is work achievement, the reward is not wages for students (Purwanto, 2011, p. 184). The Reward principle must be effective and adjusted to the level of student development. The law of study that applies to adult learners is attributed to the learning and relevant experiences of life (Danim \& Khairil, 2014, p. 128).

External stimulation, in an interesting learning situation, can stimulate the emergence of interest (Laine, Veermans, Lahti, \& Veermans, 2017). Interesting is a sense of love and attachment to something or an activity or form of acceptance of a relationship between yourself and something outside yourself, when it becomes stronger then the interest is getting bigger (Slameto, 2010, p. 180).

Expression of interest can be in the form of statement, participation in an activity, and great attention to a particular subject. Interest is not brought from birth but obtained from learning outcomes and in social relationships in learning of the psychiatric conditions is indispensable in the learning process of teaching especially in paying attention to an object. 
Behaviors are influenced by two components namely cognitive components (factual knowledge, concept, and skill) and motivational components (attitudes, psychological needs) (Volet, 2001, p. 17). Hidi \& Renninger stated that it depends on the level of previous individual knowledge and is supported by external stimuli occurring (Laine, et al., 2017).

Acquisition is the ability to minister and understand material until students can redescribe well-received material (Depdikbud, 1990). Students acquisition is used as a guideline to know the extent of students' acquisition of the lesson material taught by the teacher in the learning activities.

The assessment is conducted by measuring the achievement of basic competencies (BC) on core competencies (CC), using minimal submission criteria (MSC), which is done in a planned and ongoing basis, further analyzed to determine the level of achievement of students, as well as determining follow-up and feedback to improve the learning process. The analysis results of daily replay assessment using reference of predefined criteria in MSC (Sani, 2016, pp. 63-66). The purpose of this analysis is to determine whether students have reached MSC and can continue to follow the next BC study or still need improvement. Assessments are used to manage and improve learning progress by providing information to monitor student progress, make instructional decisions, evaluate student achievement, and evaluate programmes (Nessel, 2007, p. 16).

Students will benefit from good judgment at school and learn that educators care. If it is responsible for students ' learning, performance increases (Woodrow, 2015, pp. 25-78). Students acquisition includes academic achievement based on the learning outcomes according to the curriculum in this school To determine students' learning(individual) delivery can be calculated using the following equation.

Note:

$$
\mathrm{KB}=\frac{\mathrm{T}}{\mathrm{T}_{1}} \times 100 \%
$$

$\mathrm{KB}=$ learning Submission

$\mathrm{T}=$ number of scores earned by students $\mathrm{T} 1=$ Total score Number

Each student is said to achieve a learning submission if the proportion of the correct answer to students is $\geq 65 \%$, and a class is said to achieve a learning unity if there are $\geq 85 \%$ of students who have completed their studies (Trianto, 2011). The absorbent power results can be seen from the percentage of students who have achieved minimal submission criteria compared to all students who take the exam.

The human reproductive system is a system of living creatures that have the ability to breed, so that the species of living creatures are able to survive by forming new organisms. In humans, the reproduction occurs sexually. The human reproductive system includes reproductive organs, reproductive mechanisms, menstrual cycles, fertilization, pregnancy, birth processes, and abnormalities/diseases of the reproductive system (Pratiwi, Maryati, Srikini, \& Bambang, 2006, p. 224).

\section{METHOD}

The type of research conducted was a quasi experiment with a non-equivalent pretest-postest control group design. The research was performed at SSHS 1 Sentolo, Kulon Progo regency, Yogyakarta from April to May 2018 in Social Science $11^{\text {th }}$ grade classes. The purpose of the study is to know the influence of the point-pin reward method on the students' interest and acquisition in the cross-specialization biological learning. The subjects of the 
study were 41 students of the social science $11^{\text {th }}$ grade class. Prior to the implementation of the study, observation activities and pre- research activities were conducted. Data collection techniques were done by non-test techniques (questionnaires for students' interest before and after the learning activities), and test techniques to get the students' acquisition data from the pre-test and post test results.

This research instruments were in the form of learning devices for both classes along with the reward point-pin devices for the experimental class, measurement of students' interest using the Likert scale with a choice of 5 student responses, namely strongly agree (SA), agree (A), undecided (U), disagreeing (D), and strongly disagree (SD) (Sugiyono, 2015, pp. 134-135). For the students' acquisition instruments, the assessment tools ranged from grids, evaluation sheets, answer keys, and results of pretests and postest analyses. The instruments were used after a validation and reliability test we waswas test.

Data analysis techniques consisted of descriptive analysis and inferential analysis. The descriptive analysis was used to provide general explanation of research implementation and present the measurement data of table and diagram form. The calculation of descriptive statistics and inferential analysis using the help of SPSS 22.00 for Windows program. The inferential analysis was used to test the research hypothesis, after the prerequisite test was fulfilled, namely the normality test and the homogenity of the data group variant followed up by conducting an independent sampels $t$-test. Next to know the difference in influence of the pointpin reward method for acquisition in both classes, a gain score test was performed using SPSS 22.00 for Windows.

\section{RESEARCH RESULTS AND DISCUSSION}

The cross-specialization biological material is no different from biological material for interest in grade XI of MIPA. Generally, the material is in the even semester and includes the structure and function of organs, mechanisms of organ systems, as well as disorders, diseases or abnormalities of the organ system. Problem-based learning improves the ability to optimize students' thinking through systematic group or team work processes, so that students can empower, hone, test, and continuously develop their sustainable skills hormones that play a role in the development of human reproduction. In discussions within groups, students get an opportunity to respond and advise on the results of other group discussions. During this activity, they can get a reward. Students who are active in learning activities get pins. The criteria are as rollows: asking questions (red pin, score 1), answering questions answers (blue, score 2) and giving arguments (gold, score 3 ). This learning model shows that learning can build knowledge with others through interaction and collaboration. Learning with the reward gives a change of feeling to the learners so that it gives meaning to learners. (Watkins, Carnel, \& Lodge, 2010. p. 15). Reward point-pin is given at a certain stage during the learning activities. Meanwhile, in the control class, there is a conventional learning activity without any reward giving to students. Observations of students' activities are directly recorded by the observer. By a student's activity is meant an active participation starting from the inquiring until the opinion is recorded in the observation sheet. In the experimental classes, students who participated actively got a point for direct Pin reward, while in the control class, earning points did not get rewarded. The implementation 
of the learning activities in both classes consists of introduction, core activities and closing. At the introductory stage consists of opening, motivation, the exception and delivery of learning objectives. In the introductory phase of experiment class, the teacher provides an explanation on the implementation of the pin reward method to students who play active roles during the learning activities.

In the core learning activities, students get the opportunity to earn the point reward. The learning material in this activity is a media presentation on the signs of secondary genital development in both men and women. Students are asked to formulate questions about male and female reproductive organs as well as their relationship to puberty. In addition to the media, images of spermatogenesis and the development of ovarian follicles are displayed also. This activity is guided by a participant's activity sheet. Students conduct discussions in the group. Students also collect information from the literature and the Internet media to add information about the relationship between structure and function of reproductive organs in the events of spermatogenesis and oogenesis, as well as hormones that play a role in the development of human reproduction.

In the discussions between groups, students get an opportunity to respond and advise on the results of other group discussions. During this activity, they can get a reward. Students who are active in learning activities get pins. When a student asks a question, a red pin is given (score 1), answers a question, a blue pin is given (score 2 ), and gives an argument, a gold pin (score 3).

The point-pin reward in the next meeting is conducted from the introductory stage to the closing activity. The material for the second to the fourth meeting is about menstrual cycles, fertilization, pregnancy and childbirth, and diseases/abnormalities that interfere with the reproductive system which include mechanisms, symptoms, causes, how to cure, how to prevent, the risk of illness, and the impacts of free association. Rewards can be earned by students during group discussions, class discussions, to conclusions and giving their ideas or opinions.

Students are given the opportunity to explore vast information from either experience, events that occur in the environment, or from media sources of free association, starting from the acquisition, causal factors, as well as its impact on the health of human reproductive devices. With the active participation of students in the learning activities, learning becomes meaningful, which brings knowledge and cognitive processes that students need in problem solving (Bloom, Englehart, Walker, Furst, \& Krathwohl, 2010, p. 97). Students can illustrate and plan problem solving solutions and apply them. It is evident that during discussions between groups, ideas arise to solve problems related to the human reproductive system. The number of pins the student acquired is seen at the end of this fourth learning implementation. A star pin is attached to the reward board. The acquisition in the control class is quite noted by the observer. The average point result in both classes can be seen in the Figure 1.

The first acquisition of points in the control class was more than the point of acquisition in the experimental class. But after four times of learning, it is revealed that the average student point accrual in the experimental class is higher than the average student point accrual in the control class.

Furthermore, in the descriptions of the students' interest measurement results, each class experienced an average score increase 
Figure 1. Students' Point Acquisition

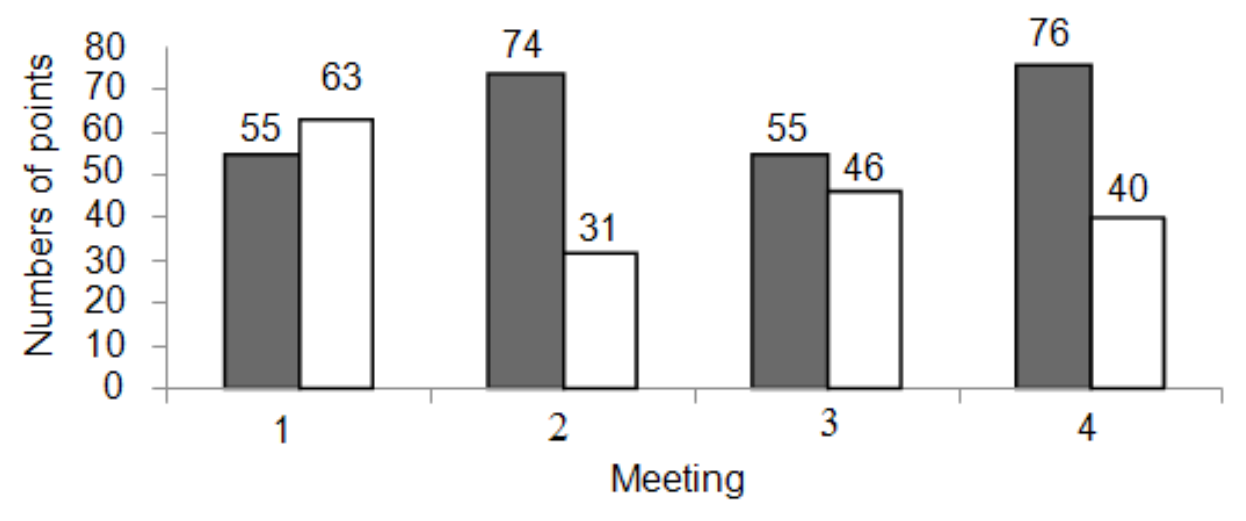

in learners from the initial condition that was before the learning activities of the final condition after learning was performed. This can be seen in Table 1.

The average interest in the experiment class increased by $8.93 \%$ while the average rate of interest in the control class was $1.70 \%$. From these results, the interest rate increase in the experiment class is greater than that of the control class score. The description presented in the study is to describe data that has been collected and does not aim to make conclusions that apply to the public or generalization (Sugiyono, 2015, p. 208).

Further testing is test normality and test homogenization of interest measurement data, as a prerequisite for inferential analysis. From the prerequisite test result, it is known that the students' interest measurement data in the experiment class (0.196) and the control class (0.462) have a significance value greater than 0.05 ; so the $H o$ is accepted, which means that the distribution of the students' interest data is normal. And the significance value of the test homogenity variant of the student interest measurement data group (0.466) is greater than the equivalent of 0.05 significance, so the $H o$ is accepted, meaning that students' interest data have a homogeneous variant. Further hypotheses is conducted using the independent-sample $t$-test that. The results can be seen in the Table 2.

Based on the data in Table 2, it is known that the value of significance (2-tailed) is

Table 1

Description of Students'Learning Interest Measurement Results

\begin{tabular}{lcccc}
\hline \multirow{2}{*}{ Description } & \multicolumn{2}{c}{ Experiment Class } & \multicolumn{2}{c}{ Control class } \\
\cline { 2 - 5 } & Early & End & Early & End \\
\hline Average & 56 & 61 & 59 & 60 \\
Average hike & $8.93 \%$ & & & $1.70 \%$ \\
Highest score & 65 & 75 & 70 & 78 \\
Lowest score & 46 & 51 & 37 & 44 \\
\hline
\end{tabular}


Table 2

Independent-sample t-test Data of The Test Results of Students'Interest Measurement

\begin{tabular}{|c|c|c|c|c|c|}
\hline \multirow[b]{2}{*}{ Student'Interest } & \multicolumn{5}{|c|}{ t-test for Equality of Means } \\
\hline & $t$ & $D f$ & $\begin{array}{c}\text { Sig } \\
\text { (2-tailed) }\end{array}$ & Mean Difference & $\begin{array}{l}\text { Std Error } \\
\text { Difference }\end{array}$ \\
\hline $\begin{array}{l}\text { Equal variances } \\
\text { assumed }\end{array}$ & 2.488 & 39 & 0,017 & 4.683 & 1.882 \\
\hline $\begin{array}{l}\text { Equal variances not } \\
\text { assumed }\end{array}$ & 2.442 & 24.211 & 0.022 & 4.683 & 1.918 \\
\hline
\end{tabular}

0.017 . The value of that significance is lower than the $\alpha$ value $(0.025)$ so that the $H o$ is rejected which means that there is a difference in the influence of the point-pin reward method in the learning activities of biology on the cross-specialization towards students of Social Science $11^{\text {th }}$ grade of SSHS 1, Sentolo, Kulon Progo. The results of measuring students' interest before and after the implementation of the learning activities show that the final interest change occurred compared with the initial interest. In the control class, the change of the initial interest and the final interest among the students with the other is not the same.

Some factors that affect students in Reward accrual include the time available to earn reward, the material presented is material that is related to the daily life of the student and the application of point-pin reward in the learning activities that have not been applied in the school. Therefore, students feel attracted by the Pin received and pasted into the Reward board. It is in accordance with the opinion of Kenneth H. Hover (Hamalik, 2015, p. 163) that the praise that comes from outside (external reward) is sometimes necessary and effective enough to stimulate the actual interest.

Williams (Sears \& Pai, 2012) stated that the influence of prizes on interactions in the group will bring about a growing motivation in learning activities. As is the case in the implementation of this Reward method, there is an increase in the attention and spirit of the students in participating in the learning activities. is an increase in the attention and spirit of the students in participating in the learning activities.

Enthusiastic learning activities were conducted to motivate students for increased student interest. As a teacher must have pedagogic knowledge and ability to carry out interesting and inspiring learning activities that can improve students' knowledge.

Teachers must have the knowledge and motivation to improve students' learning optimally (Keller, Neumann, \& Fischer, 2016). Students participating in the study will benefit from greater education and learning. Then there will be a posistive increase in the cognitive acquisition, more advanced problem solving skills, and their interests (Cress, Collier, \& Reitenauer, 2013, p. 13). The implementation of the point-pin reward method in learning activities gives an interesting activity and aims to increase the interest of students' learning of cross- specialization biology. With the increasing interest, there can also be an increase in students' learning performance.

Chen stated that biological teachers should focus on growing, stimulating, and improving students' interest in biology, activating and safeguarding students' 
enthusiasm for learning biology (Li, 2011). The learning activity with this method of point-pin reward requires the Teacher's effort to increase students' interest in biology lessons in the social class. This is demonstrated by a significant influence on students' interests.

Interest is personal, for interest will grow by itself in students. According to Herbart (Savickas \& Spokane, 1999, p. 24), interest is an attitude of thought that is indicated by attention. Without awareness and attention to something, it becomes a disinterest. In accordance with this, there is the influence of point-pin reward to interest due to the awareness and attention of students during the learning activities. Although from the beginning of the majors, students have chosen a course to the social fields and the student's interest in biology lessons is initially lacking, with the application of the point-pin reward method, this learning activity can increase students' interest.

Reward in the form of material does not have a positive influence on intrinsic and extrinsic motivation. When associated with learning activities, reward points are extrinsic motivations in the form of nonmaterial rewards (Yoon, Sung, Choi, Lee, \& Kim, 2015) This reward has a positive effect on the students. Interest and motivation are two things that relate to each other. Both are necessary so that there is a smooth learning process. Pin rewards for the $11^{\text {th }}$ grade students of the social science class can change the interest of students' learning of the cross-specialization biology subjects. This type of reward can foster the interest of students emerging from students themselves.

In the field of education, learning experience is important. Learning is an internal experience; so teachers cannot teach students until they want to learn. For adult students' the experience is a continuous process on the basis of the evaluation of the experienced (Danim \& Khairil, 2014, p. 134). Therefore, if the reward method is carried out continuously, it will give meaningful influence on the students' willingness to study and becomes the students' experience of the learning activities.

To determine the influence of the point-pin reward method on the students' acquisition in the subjects of crossspecialization biology, it can be seen from the ability of students in the mastery of the subject matter. After analyzing the results of the written tests before and after the learning activities, the students' learning has been completed compared to all students. The MSC imposed on the $11^{\text {th }}$ graders in SSHS 1, Sentolo is 70. Individual submission is known by a percentage score ratio achieved by the total score (Trianto, 2011). A description of the acquisition measurement results can be seen in Table 3 .

Based on Table 3 the average scores of he pre-tests and post tests increase in both the experimental class and the control class. The standard deviation in both classes shows a decline, in which the decreases the standard deviation in the experimental class is greater than 3.768. Meanwhile, in the students' acquisition.

Based on the Figure 2, an increase in the grade of power of students in a class with a reward point-pin method is greater than the control class. This indicates that the awarding of rewards given to students can develop students' knowledge on a regular basis. The award encourages cognitive stability in terms of increased context or cue- keeping (Hefer \& Dreisbach, 2017) and can change behavior after intensive learning by motivating individuals to increase their efforts.

Data, both of the classes improve. The increase in acquisition in the experimental 
Table 3

Description of Pretest Results Measurement, Posttest, and Acquisition

\begin{tabular}{lcccc}
\hline \multirow{2}{*}{\multicolumn{1}{c}{ Description }} & \multicolumn{2}{c}{ Experiment Class } & \multicolumn{2}{c}{ Control Class } \\
\cline { 2 - 5 } & Pretest & Posttest & Pretest & Posttest \\
\hline Average & 42,58 & 68,97 & 50.57 & 61,71 \\
Average hike & $61.98 \%$ & & $22.03 \%$ & \\
Highest score & 71 & 77 & 66 & 71 \\
Lowest value & 20 & 49 & 44 & 40 \\
Standard deviation & 10.724 & 6.956 & 7.304 & 7.083 \\
Acquisition (\%) & 48 & 77 & 55 & 68 \\
Acquisition power increase & $60.41 \%$ & & $23.64 \%$ & \\
\hline
\end{tabular}

Figure 2. Increased of The Students' Acquisition

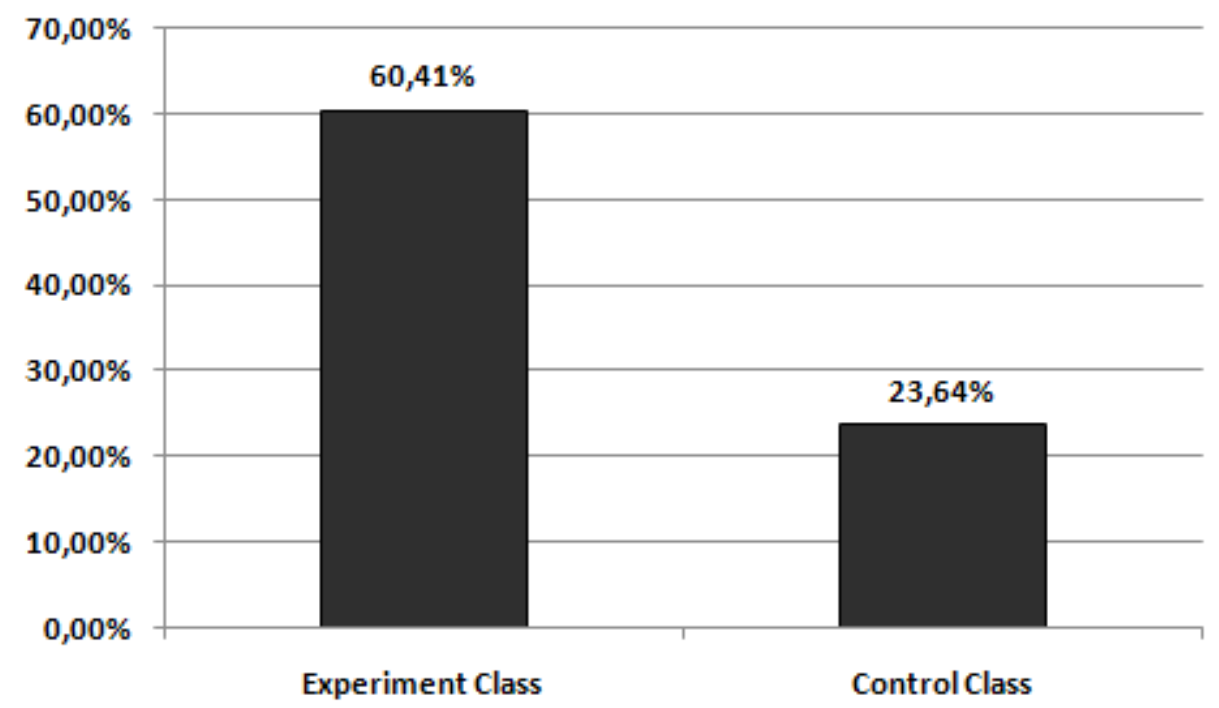

class is $60.41 \%$, which is greater than the absorbent power in the control class of $23.64 \%$. The increased acquisition in both classes can be seen in Figure 2. Rewarding efforts have proven the improvement in students' knowledge scores (Freedberg, Schacherer, \& Hazeltine, 2016).

Once the pretests is tested for homogenity and normality, thestatistical test is conducted. The hypothesis for the results of the test influence of the point- pin reward method to the the students' acquisition uses the independent-sample $t$-test. The results can be seen in Table 4 .

Based on Table 4, it is known that the value of significance (2-tailed) is 0.002 . The value of the significance is lower than the $\alpha$ value (0.025); then the Ho is rejected which means that there is a significant difference in the effect of applying the point-pin reward method of biological learning activities to the student acquisition. 
Table 4

Results of The Independent-Sample t-Test of Students' Acquisition

\begin{tabular}{lccccc}
\hline \multirow{1}{*}{$\begin{array}{c}\text { Students } \\
\text { Acquisition }\end{array}$} & $T$ & $d f$ & $\begin{array}{c}\text { Sig(2- } \\
\text { tailed) }\end{array}$ & $\begin{array}{c}\text { Mean } \\
\text { Difference }\end{array}$ & $\begin{array}{c}\text { Std Error } \\
\text { Difference }\end{array}$ \\
\cline { 2 - 6 } & 3.278 & 39 & 0.002 & 7.107 & 2.188 \\
$\begin{array}{l}\text { Equal variances } \\
\text { assumed }\end{array}$ & 3.273 & 38.567 & 0.002 & 7.107 & 2.171 \\
$\begin{array}{l}\text { Equal varianc not } \\
\text { assumed }\end{array}$ & & & & & \\
\hline
\end{tabular}

There is an influence on the implementation of the point-pin reward method against acquisition power, and students will get a considerable achievement of learning, especially the ongoing learning activities supported for the dissemination of science culture and social awareness (Kececi, 2017). This indicates to be a significant difference after the implementation of the learning activities. The point-pin reward provides motivation that stimulates students in increasing their capacity. This is indicated by changes in behavior during the learning activities. In the same way, the results of research on awarding and punishment by Rondonuwu, Kaunang, and Rogahang (2015) indicate that awarding of rewards can improve the metacognitive skills and learning outcomes of the students.

Furthermore, a test can provide an overview of the improved learning score between before and after the point-pin reward method is applied in the learning activity. The gain score test is performed to determine the influence of the methods on the students' acquisition. The gain-score test results can be seen in the Table 5. The experiment group $(\mathrm{M}=21.10)$ has a higher score change compared to the control group $(M=10.94)$ (Widhiarso, 2011). Furthermore, the results of the Independentt sample gain score test can be seen in the Table 6 .

Based on the data in Table 6 , it is revealed that data $(F=1.371 ; \mathrm{p}>0.05)$ is homogeneous. This means that there is no variance between the experiment group and the control group. Or it can be stated that the data variation of both groups is the same. As also known in the column of equal variances assumed, there is a difference in the level of 1 percent $(t=3.080 ; \mathrm{p}<0.01)$, meaning that the experiment group has a significant change compared to the control group. The description shows that the treatment given to the experiment group is successful.

Characteristic of the learning process, the learning activities are active processes, where rewards given during learning activities allow students to engage actively (Danim \& Khairil, 2014, p. 121). Students' attitudes can develop or change when they

Table 5

Results of The Gain-score Test of students' acquisition

\begin{tabular}{lcccc}
\hline \multicolumn{1}{c}{ Gain } & $\mathrm{N}$ & Mean & Std. Deviation & Std. Error Mean \\
\hline Experimen & 21 & 21.1010 & 12.26309 & 2.67602 \\
Control & 20 & 10.9400 & 8.39512 & 1.87721 \\
\hline
\end{tabular}


Table 6

Results of The Independent Samples Gain-score Test

\begin{tabular}{|c|c|c|c|c|c|c|c|c|c|}
\hline \multirow{3}{*}{ Gain } & \multicolumn{2}{|c|}{$\begin{array}{c}\text { Levene's Test } \\
\text { Equality for } \\
\text { Variances }\end{array}$} & \multicolumn{7}{|c|}{$t$-test for Equality of Means } \\
\hline & \multirow{2}{*}{$F$} & \multirow{2}{*}{ Sig } & \multirow[t]{2}{*}{$t$} & \multirow{2}{*}{ df } & \multirow{2}{*}{$\begin{array}{l}\operatorname{Sig}(2- \\
\text { tailed) }\end{array}$} & \multirow{2}{*}{$\begin{array}{l}\text { Mean } \\
\text { Diff. }\end{array}$} & \multirow{2}{*}{$\begin{array}{l}\text { Std. } \\
\text { Error } \\
\text { Diff. }\end{array}$} & \multicolumn{2}{|c|}{$\begin{array}{l}95 \% \text { Confidence } \\
\text { Interval of the Diff }\end{array}$} \\
\hline & & & & & & & & Lower & Upper \\
\hline $\begin{array}{l}\text { Equal Variances } \\
\text { Assumed }\end{array}$ & 1.371 & 0.249 & 3.080 & 39 & 0.004 & 10.16095 & 3.29851 & 3.48909 & 16.83281 \\
\hline $\begin{array}{l}\text { Equal Variances } \\
\text { Not Assumed }\end{array}$ & & & 3.108 & 35.482 & 0.004 & 10.16095 & 3.26879 & 3.52817 & 16.79373 \\
\hline
\end{tabular}

react emotionally in response to stimuli. As external motivation, rewards can be the spirit of students in the mastery of a subject matter. Learning also depends on the consequences that cause it (Slameto, 2010, p. 112).

This means that this learning activity has given a pleasant, interesting, relieving tension beneficial in expanding knowledge in efficient and durable ways. In addition, gift-giving learning activities help students in material mastery because of the support of fun and interesting learning situations. In a similar way, the pin reward gives the students an immersive experience and impression.

Measuring the achievement of students' learning outcomes in this class is conducted based on class-based assessments, where the data and information obtained is one of the evidence that can be used to measure the achievement of education programs. Class- based assessments are the process of collecting, reporting, data usage and data information about students' learning outcomes to set the level of achievement and mastery of students on basic competencies (Arifin, 2013, p. 180). An authentic assessment is used to determine the level of students' ability in competency mastery. With the significant influence of the implementation of the point-pin reward method on the acquisition of students, providing the progress of learning outcomes improves the next learning activities and stimulates students to make improvement. The increase in learning outcomes earned by students is encouraged by the sense of the needs to obtain acceptance from other individuals such as parents. Students who perform well aim to seek fame and award needs (Slameto, 2010, pp. 172-173).

Strengthening of rewards for students in high school (grades X-XII) is more focused if the presented material is closely related to their own lives (Santrock, 2011, pp. 198-254). The human reproductive system is a material inherent in the lives of students everyday, making it very supportive in the application of this method. The rewards given in the form of this pin, have not been given so that, among students, they can have a different perception. Although the students' initial interest is in the field of social sciences, the application of the point-pin reward has affected the students' interest and acquisition in biological subjects. 


\section{CONCLUSION}

The results of the study concludes that the point-pin reward method is influential for the the students' interest and acquisition in cross- specialization biology learning activities.

\section{REFFERENCES}

Arifin, Z. (2013). Evaluasi pembelajaran. Bandung: Remaja Rosdakarya.

Arikunto, S.(1990). Manajemen pengajaran secara manusiawi. Jakarta. PT. Rineka Cipta. Armstrong, M., \& Brown, D. (2006). Strategic reward making it happen. London: The British Library.

Bloom, B. S. (Ed.), Englehart, M. D., Walker, H., Furst, E. J., \& Krathwohl, D. R. (2010). The taxonomy of educational objectives, the classification of educational goals, handbook I: Cognitive domain. (Terj.: Agung Prihantoro). Jakarta: Pustaka Pelajar.

Chahal, G. (2008). The dream, how $i$ learned the risks and rewards of entrepreneurship and made millions. New York: St. Martin's Press LLC.

Cress, C. M., Collier, P. J., \& Reitenauer, V. L. (2013). Learning through serving: A student guidebook for service-learning and civic engagement across academic disciplines and cultural communities ( $2^{\text {nd }}$ ed.). Virginia: Stylus Publishing.

Danim, S., \& Khairil, H. (2014). Psikologi pendidikan. Bandung: Alfabeta.

Delves, D. P. (2004). Stock options and the new rules of corportate accountability, measuring, managing and rewarding executive performance. New York: The McGraw-Hill Companies, Inc.

Departemen Pendidikan dan Kebudayaan. (1990). Kamus besar bahasa Indonesia. Jakarta: Balai Pustaka.

Downing, J. P. (1997). Creative teaching: Ideas to boost student interest.United States: ABC-CLIO.
Freedberg, M., Schacherer, J., \& Hazeltine, E. (2016). Incidental learning of rewarded associations bolsters learning on an associative task. Journal of Experimental Psychology: Learning, Memory, and Cognition, 42(5), 786.

Hamalik, O. (2015). Proses belajar mengajar. Jakarta: Bumi Aksara

Hamid, R. (2006). Reward dan punishment dalam perspektif pendidikan Islam. Jurnal Kopertis Wilayah XI Kalimantan, 4(5).

Hefer, C., \& Dreisbach, G. (2017). How performance-contingent $\mathrm{r}$ e $\mathrm{w}$ a $\mathrm{r} d$ prospect modulates cognitive control: Increased cue maintenance at the cost of decreased flexibility. Journal of Experimental Psychology: Learning, Memory, and Cognition, 43(10), 1643-1658. http://dx.doi.org/10.1037/ xlm0000397.

Kececi, G. (2017).The aims and learning attainments of secondary and high school students attending science festivals: A case study. Educational Research and Reviews, 12(23), 1146 -1153. DOI: 10.5897/ ERR2017.3378.

Keller, M. M., Neumann, K., \& Fischer, H. E. (2017). The impact of physics teachers' pedagogical content knowledge and motivation on students' achievement and interest. Journal of Research in Science Teaching, 54(5), 586-614.

Laine, E., Veermans, M., Lahti, A., \& Veermans, K. (2017). Generation of Student Interest in an Inquiry-Based Mobile Learning Environment. Frontline Learning Research, 5(4), 42-60.

Lee, J., Puig, A., \& Lee, S. M. (2012). The effect of the demand control and effort reward imbalance models on the academic burnout of Korean 
adolescents. Asia Pacific Journal of Education, 32(1), 113-123.

Li, Y. (2011). On the cultivation of students' interests in biology teaching. International Education Studies, 4(2), 141-143.

Marno, \& Idris, M. (2010). Strategi \& metode pengajaran. Yogyakarta: Arruzz Media.

Menteri Pendidikan dan Kebudyaan. (2016). Permendikbud Nomor 22 Tahun 2016 tentang Standar Isi Pendidikan Dasar dan Menengah. Jakarta: Kementerian Pendidikan dan Kebudayaan.

National Research Council. (2003). Engaging schools: Fostering high school students' motivation to learn. Washington D. C.: The National Academies Press.

Nessel, D. D., \& Graham, M. (2007). Thinking strategies for student achievement. Thousand Oaks: Corwin Press.

Pratiwi, D. A., Maryati, S., Srikini, S., \& Bambang, S. (2006). Biologi untuk SMA kelas XI. Jakarta: Erlangga.

Purwanto, N. (2011). Ilmu pendidikan teoritis dan praktis. Bandung: Rosdakarya.

Rondonuwu, I. P, Kaunang, E. S. N., \& Rogahang, F. H. N. (2015). Pemberian reward dan punishment dalam meningkatkan keterampilan metakognitif peserta didik di SMA Negeri 1 Tompaso. JSME MIPA UNIMA, 3(2).

Sani, R. A. (2016). Penilaian autentik. Jakarta: Bumi Aksara.

Santrock, J. W. (2011). Psikologi pendidikan. Jakarta: Penerbit Salemba Humanika.

Savickas, M. L., \& Spokane, A. R. (Eds.). (1999). Vocational interests: Meaning, measurement, and counseling use. California: Davies-Black Publishing.
Sears, D. A., \& Pai, H. H. (2012). Effects of cooperative versus individual study on learning and motivation after rewardremoval. The Journal of Experimental Education, 80(3), 246-262.

Slameto. (2010). Belajar dan faktor-faktor yang mempengaruhinya (Cet. 5). Jakarta: Rineka Cipta.

Sugiyono. (2015). Metode penelitian pendidikan. Bandung: Penerbit Alfabeta.

Trianto. (2011). Model-model pembelajaran inovatif berorientasi konstruktivistik (Cetakan kelima). Jakarta: Prestasi Pustaka Publisher.

Volet, S., \& Jarvela, S. (2001). Motivation in learning contexts theoretical advances and methodological implications. Oxford: Elsevier Science Ltd.

Watkins, C., Carnel, E., \& Lodge, C. (2010). Effective learning in classroom. London: SAGE Publications Ltd.

Widhiarso, W. (2011) Mengaplikasikan uji-t untuk membandingkan gain score antar kelompok dalam eksperimen. Yogyakarta: Fakultas Psikologi UGM.

Woodrow Jr., G. (2015) The pyramid approach a framework for raising student academic achievement. London: The Rowman \& Littlefield Publishing Group, Inc.

Yoon, H. J., Sung, S. Y., Choi, J. N., Lee, K., \& Kim, S. (2015). Tangible and intangible rewards and employee creativity: The mediating role of situational extrinsic motivation. Creativity Research Journal, 27(4), 383-393. DOI: 10.1080/10400419.2015.1088283.

Zain, A. N. M. (2017). The effect of instructional congruence on students interest towards learning science. European Journal of Physics Education, 1(1), 20-27. 